УДК 327.8

\title{
THE ECONOMIC SANCTIONS AS THE INSTRUMENT OF FOREIGN POLICY
}

\section{ЕКОНОМІЧНІ САНКЦІЇ ЯК ІНСТРУМЕНТ ЗОВНІШНЬОЇ ПОЛІТИКИ}

\section{ЭКОНОМИЧЕСКИЕ САНКЦИИ КАК ИНСТРУМЕНТ ВНЕШНЕЙ ПОЛИТИКИ}

\author{
Sedliar Y. O.
}

Doctor of science, professor of the Department of Political Science, International Relations and Social Communications of Mykolayiv National University after V. O. Sukhomlynsky, E-mail: juliasedlyar@gmail.com

\section{Седляр Ю. О.}

Доктор політичних наук, професор кафедри політології, міжнародних відносин та суспільних комунікацій Миколаївського національного університету імені В. О. Сухомлинського, E-mail: juliasedlyar@gmail.com

Седляр Ю. А.

Доктор политических наук, профессор кафедры политологии, международных отношений и общественных коммуникаций Николаевского национального университета имени В. А. Сухомлинского, E-mail: juliasedlyar@gmail.com

Abstract. The article surveys the definitional issues of the economic sanctions in the international relations theory. It opens with a review of the conceptual background of the economic sanctions through the prism of the methodological approaches of political realism, liberalism and constructivism and then goes on to explore the variables of the efficiency of economic sanctions as foreign policy tool. In conclusion, we discuss the suggestions for perspectives of further research and development of economic sanctions in the foreign policy analysis.

Key words: economic sanctions, foreign policy, foreign policy tool, international relations theory, efficiency of economic sanctions.

Анотація. У статті розглядаються чинники, щзо визначають природу економічних санкцій у теорії міжнародних відносин. Виклад розпочинається з висвітлення концептуальних засад дослідження економічних санкиій у розрізі методологічного підходу політичного реалізму, лібералізму та конструктивізму. 3'ясовуються обставини, щуо обумовлюють ефективність використання економічних санкиій як інструмента зовнішньої політики держав. Оиінюються перспективи подальших наукових розвідок з особливостей застосування економічних санкиій, насамперед у розрізі зовнішньополітичного аналізу.

Ключові слова: економічні санкиії, зовнішня політика, інструмент зовнішньої політики, теорія міжнародних відносин, ефективність економічних санкиій.

Аннотация. B статье раскрываются факторы, определяющие природу экономических санкиий в теории международных отношений. Изложение материала начинается с рассмотрения концептуальных основ исследования экономических санкций в контексте методологического подхода политического реализма, либерализма и конструктивизма. Выясняются обстоятельства, обуславливающие эффективность использования экономических санкиий как инструмента внешней политики государств. Оиениваются пер- 
спективы дальнейших научных исследований экономических санкиий, прежде всего в разрезе внешнеполитического анализа.

Ключевые слова: экономические санкиии, внешняя политика, инструмент внешней политики, теория международных отношений, эффективность экономических санкций.

General statement of problem. For the past twenty five years economic sanctions acquired growing prominence in foreign policy of the great powers. The US, the EU, China and Japan employ economic sanctions in responding to the Iranian and North Korean nuclear crises that threaten their security. Economic sanctions these are means of great powers by which they seek to influence the behavior of target states, to demonstrate leadership, to resolve international conflict and to express common values. The growing centrality of economic sanctions is partially a reaction to the limits of military power exposed during difficult and protracted operations inside the territory of the former Yugoslavia, in Afghanistan, Iraq, and Libya. Moreover, military interventions in the postbipolar international relations are difficult to justify. Without any challenger on the horizon, it is highly unclear what constitutes a threat to national security that needs to be addressed with military force together with its inherent sacrifices in life and expenditure. In J. Galtung's terms: "When military action is impossible for one reason or another... economic sanctions serve as a clear signal to everyone that what the receiving nation has done is disapproved of" [Galtung, 1967: 411-412]. Above all, because economic rather than military strength is increasingly seen by states as the prime determinant of international power, economic sanctions may begin to assume an even more prominent role.

Recent researches and publications. Notwithstanding the fact that the debate on the nature of economic sanctions has been in existence for five decades, the investigation on their efficacy has not yielded satisfactory results. Scientists in the West have long argued that there is no automatic link between the effectiveness of economic sanctions in inflicting economic pain and in compelling policy changes in the target. D. Drezner, B. de Neuilly, C. Portela, emphasize that sanctions regimes with a remarkable economic impact have failed to induce changes in the conduct of target non-democratic states. D. Drezner, conversely, stresses that mere threat of economic sanctions has sometimes succeeded in bringing about the desired policy change [Drezner, 1999]. Ukrainian scientists S. Galaka [Galaka, 2003], V. Pahil [Pahil, 2000], and S. Romanenko [Romanenko, 2001] are strong supporters of this wide-spread concept. Works by contemporary researchers on issues related to the economic sanctions and financial statecraft, among whom are Margaret Doxy [Doxy, 1971], Richard N. Haass [Haass, 1998], Zachary Selden [Selden, 1999], Brendan Taylor [Taylor, 2010], play an important role in understanding the nature of economic coercion in foreign policy making, but they say a very little on how to estimate the economic sanctions effectiveness. Thus, the determinants for the success and failure of economic sanctions have not been ascertained. The inherent difficulty of the task has been further compounded by a transformation of the instrument itself in the contemporary system of international relations.

Purposes of article. The purpose of this article is to analyze the nature of economic sanctions as the tool of foreign policy within the international relations theory, because this instrument is becoming increasingly central to shaping strategic outcomes in the XXI century. After addressing some essential definitional questions, we will try to outline the progress is made in international relations scholarships in identifying the determinants of the success of economic sanctions.

Main research results. At first, we will try to conceptualize the definition of the economic sanctions in the international relations theory. There is no generally accepted definition of economic sanctions. The term "economic sanctions" is one of the more confused and confusing to have entered the lexicon and discourse of international politics. Part of the ambiguity surrounding 
the term stems from the fact that the word "sanctions" in everyday usage carries multiple meanings. According to the Oxford Concise Dictionary, the term can connote the granting of official permission or approval and, at the same time, a penalty or punishment for disobeying a law or rule [Taylor, 2010: 11]. Confusion also results from the tendency of many scholars to use the term "sanctions" interchangeably with a raft of other descriptors, such as "economic statecraft", "economic coercion", "economic warfare", "economic diplomacy" [Weintraub, 1982: X]. In the view of the above different definitions of economic sanctions we will analyze more thoroughly.

For instance, Daniel Drezner, a towering figure who made path breaking and enduring contributions to political analysis of the economic sanctions, the author of the "sanctions paradox", defines economic sanctions as "the threat or act by a nation-state or coalition of nation-states, called the sender, to disrupt economic exchange with another nation-state, called the target, unless the targeted country acquiesces to an articulated political demand" [Drezner, 1999: 2]. R. J. Ellings ascertains economic sanctions as the governmental policies that cut or curtail economic relations in order to coerce the target country(ies) into behaving in accordance with the sanctioner's(s') objectives [Ellings, 1991: 16]. G. Lopez and D. Cortright qualify economic sanctions as the "coercive foreign policy action of a nation(s) in which it intentionally suspends customary economic relations such as trade and/or financial exchanges in order to prompt the targeted nation to change its policy or behavior [Lopez and Cortright, 1998: 15]. N. Crawford determines economic sanctions as "the denial of customary interactions (strategic, economic, or social); they are intended to promote social, political, or economic change in a target state" [Crawford, 1999: 5]. According to J. Blanchard, N. Ripsman and Shambaugh, economic sanctions strategy is the particular form of the coercive foreign policy in which a state disrupts its normal economic relations with another state in order to achieve one of the following objectives: (1) to induce the targeted state to change its behavior; (2) to generate popular pressure on the government that causes it to change its policies; or (3) to provoke a coup or revolt that leads to the emergence of a new government that will act in accordance with the sanctioning state's wishes [Blanchard, Ripsman 2000: 219; Shambaugh 1999: 4]. Rennack evaluates economic sanctions like "coercive measures imposed by one country, or coalition of countries, against another country, its government or individual entities therein, to bring about a change in behavior or policies [Rennack, 2000]. American theorist in economic sanctions policy M. O'Sullivan characterizes economic sanctions as the deliberate withdrawal of normal trade or financial relations for foreign policy purposes [O'Sullivan, 2003: 12].

Theorists in international politics distinguisheconomic sanctions from economic wars. For instance, R. Pape illustrates the difference between these two categories. According to the scientist, economic sanctions "seek to lower the economic welfare of a target state by reducing international trade in order to coerce the target government to change its political behaviour" [Pape, 1997: 93-94]. By contrast, an economic war takes place "when a state threatens to inflict economic harm... in order to persuade the target state to agree to terms of trade more favorable to the coercing state" [Pape, 1997: 94].

Economic sanctions operate in a similar way to military warfare. Both share the same end, the "political disintegration of the enemy so that he gives up the pursuit of his goals. The method used is value deprivation" [Galtung, 1967: 386]. The theory foresees a roughly proportionate relation between both phenomena: the more intense the value-deprivation, the more widespread the political disintegration in the target state. J. Galtung explains: "The idea is that there is a limit to how much value deprivation the system can stand, and that once this limit is reached (resulting in a split in leadership or between leadership and people), then political disintegration will proceed very rapidly and will lead to surrender or willingness to negotiate" [Galtung, 1967: 388]. 
Thus, two central definitional elements can be discerned in the concept of economic sanctions: the coercive measures need to be economic in nature and its aim needs to be political.

It is necessary to note that the basic methodological approaches to the study of the nature of economic sanctions as the tool of foreign policy formed over decades within the paradigm of realism, liberalism and constructivism.

Realism is concerned with the efficient use of economic sanctions for the pursuit of national interests. Realists conceptualize (economic) sanctions not as punishment on illegal or immoral acts but as a state's foreign-policy instrument used for the pursuit of national egoistic interests. In classical definition of the realism, sanctions entail "the deliberate government-inspired withdrawal of trade or financial relations to obtain foreign policy goals" [Hufbauer, 1985:2]. James Barber defined economic sanctions simply as "economic measures directed to political objectives" [Barber, 1979: 367].

Realist scholars of economic sanctions assume that:

1) a primary sanctioner in world politics is not a collective international actor as international organization, but state;

2) economic sanctions are not measure of law enforcement but a foreign policy instrument;

3 ) the key role of economic sanctions on the world stage is not to reduce the number of deviant acts but is to coerce the target state to fulfill a sanctioning country wishes;

4) economic sanctions are realized in the anarchical international system which consists of states as the primary actors.

Realists explain the nature of economic sanctions through the logic of power, interests, and rationality. All are attributes of states' power, not of structure. In this context E. H. Carr notes that "The economic weapon is pre-eminently the weapon of strong powers" [Седляр, 2013: 72]. Hossein G. Askari, for instance, emphasizes: "The imposition of economic sanctions, whether in the form of embargoes, blockades, or other economic restrictions, requires the accompanying resources and means to enforce the sanctions and that the sender country commands significant influence over commercial activities. This is a capacity of the largest and most powerful nation-states and international entities. Yet, the asymmetry of power does not negate a small state's use of economic sanctions" [Askari, 2003: 4].

Thus, realists assume that a state is more or less rational actor. Without this assumption realists cannot explain the asymmetrical use of economic sanctions among states. This is because the majority of states' non-use of economic sanctions cannot be explained solely by the logic of opportunity. It is not physically difficult for small states to stop or restrict import from or export to another country. It is also hard to believe that conflicts of interests between a small state and a big power do not exist. Then, why does not the former impose economic sanctions on the latter? Realists must argue that this is because policymakers in a small state are not irrational enough to have the willingness to impose economic sanctions that are unlikely to be successful for changing target's behaviors. The rationality assumption is the hard core of realist approach [Седляр, 2013: 72-75].

On the other hand, liberalists borrowed their ideas of economic sanctions from municipal laws. Overall, the nature of economic sanctions within liberalism can be characterized by the following provisions: 1) economic sanctions should be applied by the international organization in order to maintain international peace and security. For instance, Quincy Wright claimed that the use of sanctions must be authorized by an international organization [Wright, 1965: 206].

Liberalists argue that the United Nations Security Council applies economic sanctions to deal with four different categories of threats to international peace and security:

1) armed conflict between states;

2) armed conflict within states; 
3) international norm-breaking states (the so-called "rouges"); and

4) international terrorism [Charron, 2011: 1-8].

They stress that: economic sanctions are applied in the international system which is not anarchical, but should be understood as community that is composed of state and none-state actors who share common interests; economic sanctions should be governed not by power politics but by the rule of law. Moreover, liberal scholarship proves that the use of the mechanism of economic coercion should be regulated not by the balance of power but by collective security [Cedляр, 2013: 71].

How does collective economic sanctions system work? M. S. Daoudi and M. S. Dajani summarize liberal arguments articulated in the interwar period concisely:

1. The balance of power system is dead. It has failed to prevent wars and maintain the peace. What is the alternative?

2. By the establishment of an international organization. How will this system enforce the law without military conflicts?

3. By the establishment of international economic sanctions. This weapon is powerful, effective, relatively cheap, bloodless, and moreover, easy to use to bring any aggressor to knees.

4. Economic sanctions have a moral power. They enjoy universal public support.

5. States are innately rational. With the economic threat hanging over their heads, they will not find it worthwhile to deliberately wage wars aggression.

6. Neutrality is a precarious concept which the community of nations needs to abandon [Daoudi and Dajani, 1983: 18-19].

Liberal ideas of economic sanctions were based on domestic analogy. As Kim Richard Nossal notes, "The 'League experiment' was explicitly designed to bring the conditions of domestic order to the international system. A set of rules was laid out in the Covenant; transgressors were threatened with the imposition of clearly specified hurtful penalties if they broke the 'law'; and the penalties were to be exacted by an institution that was supposed to come as close to being an international public authority as possible. The penalties against a Covenant breaking state - harms legitimized by the international community - had all of the structural properties of punishment as we know it in a domestic context" [Nossal, 1989: 310-311].

Member-states must prioritize collective interests over national interests for maintaining collective security system. As Arnold Wolfers notes, "it was the basic assumption of all collectivist thinking that with the establishment of the League of Nations a universal community of nations had come into existence, to be the acting center of world affairs. The individual sovereign nations were merely the parts of an embracing whole, to which they and their inhabitants owed loyalty. National interests in the traditional sense of the word, therefore, should be subordinated to the interests of the community" [Wolfers: 1962: 268-269].

Liberalists assume the existence of laws and/or norms for the constitution of economic sanctions. According to liberal paradigm, there are no economic sanctions without common norms or laws that specify deviant behaviors. The distinction between coercion and sanctions is important in liberal paradigm. The possession of coercive power is not a sufficient, albeit necessary, condition for the resort to sanctions. Sanctions are coercive acts but not all coercive acts are sanctions. Sanctions are coercion that is used for promoting common interests. All coercive acts from self-interest are treated as acts of hostility, not sanctions. Liberalists believe that norms or laws must preexist for the exercise of economic sanctions because they work as constitutive rules that specify which practices are counted as legitimate coercion, that is, sanctions. Liberal scholars of sanctions consider that economic sanctions are modern phenomena. States started to engage in the practice of sanctions, they believe, only after international system was transformed into international society [Koga, 2005: 45-49]. 
At last, constructivism as the methodological approach in the international relations theory holds the view that: economic sanctions are not objective phenomenon, but the social construction is shaped by shared ideas as well as material forces; economic sanctions are based on the identities and interests of political actors are shaped primarily by shared ideas [Wendt, 1999: 1]. Constructivism does not specify empirical puzzles, the nature of economic sanctions, international system, key political actors in international society, their preferences, and the logic of actions in international politics. This is what Alexander Wendt calls "a variation question" of constructivist analysis [Wendt, 1999]. To paraphrase his expression, there is no such thing as "logic". That is why there is no logic in economic sanctions. Thus, economic sanctions are not a brutal fact, nor rational fact. They are social entity that cannot be reduced to material entity. In other words, economic sanctions are the means by which social construction of reality has been created. What is the main goal of economic sanctions in international policy? According to constructivists, the sanction strategy is aimed to ensure common values in the international society but not in the international system which is based on the power balance whether normative rules of the international institutions.

Theorists in international politics are primarily interested in answering two questions: 1) do economic sanctions work?; and 2) under what conditions do economic sanctions work?

The determinants of the efficiency of economic sanctions in international relations studies could be characterized by the following provisions:

- economic sanctions are to be designed to maximize pressure on the culpable actors, to inflict pain and suffering upon the leaders whose policy the sender tries to influence. Sanctions should be appropriately targeted to minimize humanitarian impact on population in the objective state;

- the evidence from the cases suggests that the presence of political opposition in the target which oriented on sanctioning state makes economic sanctions more fruitful. The political groups that lose from economic sanctions will find themselves in a financially diminished position, which may reduce their political influence. The "fifth column" effect is probable response of groups in the political elite of the target to economic sanctions and that rely on imports or export-oriented producers;

- scientists in international relations stress that economic sanctions are of limited utility in achieving foreign policy goals like regime change and democratization. The security, political or other costs of complying with the sender demands may simply be higher than any pain that can be imposed with economic sanctions. That is why economic sanctions succeed if they are designed to achieve moderate political goals in the target;

- multilateral cooperation among the sanctioning states is a necessary and/ or sufficient condition for generating a successful outcome. In this regard, scientists in international politics have observed that cooperation problems can be parsed into bargaining and enforcement phases. Cooperation could be sabotaged by bargaining difficulties and / or a lack of enforcement. Economic sanctions involving multilateral cooperation involve two separate cooperation dilemmas: one between the sanctioning states and the target, and one between the primary sanctioner and other sanctioners. Without the support of an international organization, ad hoc coalitions of sanctioners are inherently fragile. International organizations are the coordinating mechanism for reassurance and information. They enable governments to resist domestic pressure, and provide side payments to increase the value of continued cooperation [Drezner, 2000].

- theorists in international politics assume that economically punishing sanctions are less likely to succeed against a nondemocratic target than they are against a democratic target. The reason for this conditional relationship is twofold. First, sanctions increase a leader's ability to 
extract rents. Greater rents increase a nondemocratic leader's ability to hold onto power, but greater rents do not increase a democratic leader's ability to retain office. Second, the pressure to yield to sanctions depends critically on who is bearing the brunt of the costs in the targeted state. To succeed, sanctions need to target the regime's winning coalition, the size and composition of which depend on a state's political institutions. Against a democracy, where the winning coalition is large, economic sanctions are more likely to produce a policy change if they are relatively broad and affect many groups in society. Sanctions that are high in cost will generally have this effect. When dealing with nondemocratic countries, states should avoid broad sanctions that impose high economic costs on the population at large because most people in the country are not part of the autocratic leader's winning coalition, so the economic costs imposed on the larger population do not translate into political costs for the regime. In brief, because nondemocratic leaders generally have a narrowly defined winning coalition, broad and costly sanctions will be less successful against them than against democratic countries. To make nondemocratic leaders yield, states must be able to impose narrow sanctions affecting the core groups supporting the regime [Portela, 2010].

Conclusions. Summing up the above mentioned we admit that economic sanctions as the foreign policy tool that prescribes the disruption of economic relations in order to coerce the target state to change disapproved policy. Theorists assume that the main goal of economic sanctions is to change target country's behavior as desired by a sanctioning state. Thus, scientists suppose that compellence is the main aim which pursues sanctioning country. Other goals of economic sanctions are specific deterrence, weakening, international and domestic symbolism.

Scholars are unanimous in the opinion that economic harm leads to political disintegration brought about by an unwillingness of the population in the target country to suffer economically because of internationally unpopular policy.

It is determined that the key methodological issue of identifying the variables of the economic sanctions efficiency remains unresolved in international relations scholarship. It was found that none of the three schools discussed above has emerged uncontested through its capacity to provide an unequivocal answer to the puzzle of why economic sanctions in some cases fail to achieve desirable outcome. Generally, the study determined that the policy of economic sanctions effectiveness as a mechanism of the states' national interestsquarantee depends on the wide international political support of the sanctions on the part of the great states on all stages of their implementations. It is provided by the coincidence of their national interests in the target country and foreign political attraction of the geopolitical surrounding states of the target country towards realization of the sanctioned measures. The policy of economic sanctions effectiveness also depends on such a factor as the formed normative and legal base which defines the principles and regulates the peculiarity of the policy of economic sanctions implementation related to the target country. The next factors are: institutional providing of the sanctioned measures realization; export and import dependence of the target country on the state-sanctioner which is often quaranteed by the previous positive political relationships between the state-sanctioner and the objective state. It also depends on the moderation of diplomacy goals the policy of sanctions is aimed at, which are to be corrected in the foreign political activity of the objective state but are not directed on the changing of political regime in the target country. Additional factor is the presence of formed political opposition in the objective country which is oriented on the state which realizes the policy of sanctions, demonstrate readiness to satisfy its goals when the mechanisms of the population influence on making political decisions exist.

Prospects for further research and development of the issues raised in this article are to conceptualize the determinants of the efficiency of economic sanctions which have been introduced against Russia for the annexation of Crimea, and for backing separatists in eastern Ukraine. 


\section{References}

1. Galtung $J$. (1967) 'On the Effects of International Economic Sanctions. With Examples from the Case of Rhodesia', World Politics, Vol. 19, No. 3, P. 378-416.

2. Drezner D. (1999) 'The Sanctions Paradox. Economic Statecraft and International Relations' $342 \mathrm{p}$.

3. Galaka S. (2003) 'PolitykaSShA v galuzi yadernoho nerozpovsudzhenja na pochatku 1990tyh rokiv' [US nonproliferation policy at the beginning of the 1990s], Visnyk Kyivskoho nazionalnoho universytetu imeni Tarasa Shevchenka. Mizhnarodni vydnosyny 27, P. 185188.

4. Pakhil V. (2000) 'Problemasankciy v diyalnosti OON' [Problem of sanctions in the UN activity], Dissertacija kand. nauk. Kyivskiy nazionalnyi universytet imeni Tarasa Shevchenka, $198 \mathrm{p}$.

5. Romanenko S. (2001) 'Problema sankciyu zovnishniy polityci SShA (1990-2000 roky)' [Problem of sanctionsin the US Foreign Policy (1990-2000 years)], Dissertacija kand. nauk. Kyivskiy nazionalnyi universytet imeni Tarasa Shevchenka, $216 \mathrm{p}$.

6. Doxey M. (1971) 'Economic Sanctions and International Enforcement', 162 p.

7. Haass R. (1998) 'Economic Sanctions and American Diplomacy', 222 p.

8. Selden Z. (1999) 'Economic Sanctions as Instruments of American Foreign Policy', 147 p.

9. Taylor B. (2010) 'Sanctions as Grand Strategy', 123 p.

10. Weintraub S. (1982) 'Economic Coercion and US Foreign Policy: Implications of Case Studies from the Johnson Administration', $234 \mathrm{p}$.

11. Ellings, R. J. (1999) 'The End of Economic Sanctions?' in Private Property and National Security: Foreign Economic Sanctions and the Constitution. R. J. Ellings, H. Gregorian, M. Leigh and J. A. Swindler. Washington, DC, The National Legal Center for the Public Interest, P. 15-29.

12. Economic Sanctions Panacea or Peacebuilding in a Post-Cold War World? (1998), 231 p.

13. Crawford N., Klotz A. (1999) 'How Sanctions Work: Lessons from South Africa', 292 p.

14. Blanchard J., Ripsman N. (2000) 'Asking the Right Question: When Do Economic Sanctions Work Best?', Security Studies, Winter, P. 219-253.

15. Shambaugh G. E. (1999) 'States, Firms, and Power: Successful Sanctions in United States Foreign Policy' 248 p.

16. Rennack D. E. (2000) 'Economic Sanctions: Legislation in the 106th Congress. Congressional Research Service Reports'. Available at: <http://www.ncseonline.org/nle/crsreports/international/inter21.cfm? \&CFID $=3378804 \&$ CFTOKE $=48114672>$

17. O'Sullivan M. (2003) 'Shrewd Sanctions: Statecraft and State Sponsors of Terrorism', 424 $\mathrm{p}$.

18. Pape R. (1997) 'Why Economic Sanctions Do Not Work', International Security, Vol. 22, Fall, P. 90-136.

19. Hufbauer G., Schott J., Elliot K. (1985) 'Economic Sanctions Reconsidered: History and Current Policy', 798 p.

20. Barber J. (1979) 'Economic Sanctions as a Policy Instrument', International Affairs, No 55 (July), P. 367-384.

21. Sedliar Y. A. (2013) 'Strategia ekonomicheskih sankciy v mezhdunarodno-politicheskoinauke' [Strategy of economic sanctions in the international political science], Voprosypolitologii 4, P. 67-78.

22. Askari H. (2003) 'Economic Sanctions: Examining Their Philosophy and Efficacy', 223 p.

23. Wright Q. A. (1965) 'Study of War' 1637 p. 
24. Charron A. (2011) 'UN Sanctions and Conflict. Responding to Peace and Security Threats', $226 \mathrm{p}$.

25. Daoudi M., Dajani M. (1983) 'Economic Sanctions: Ideals and Experience', 263 p.

26. Nossal K. (1989) 'International Sanctions as International Punishment', International Organization, No. 43 (2), P. 301-322.

27. Wolfers A. (1962) 'Discord and Collaboration: Essays on International Politics', 283 p.

28. Koga Y. (2005) Constructivist Approach of International Sanctions: Realism, Liberalism, Cosmopolitanism, and Hegemonism / Y. Koga PhD candidate, Department of Political Science University of Pittsburgh. Paper prepared for presentation at the Istanbul International Conference (Istanbul, Turkey, August 24-27, 2005). - 85 p. Available at: $<$ http://www.sanctio.jp/wordpress/wp-content/uploads/2010/06/Constructivist-Approach-of-InternationalSanctions-by-Yoshifumi-KOGA1.pdf $>$

29. Wendt A. (1999) 'Social Theory of International Politics' 429 p.

30. Drezner D. (2000) 'Bargaining, Enforcement, an Multilateral Sanctions: When is Cooperation Counterproductive?', International Organization, Winter, P. 73-102.

31. Portela C. (2010) 'EU Sanctions and Foreign Policy. When and why do they work?', 206 p. 